\title{
Hormonal and photoperiod-induced changes in testicular interleukin-1-like factor in bank voles, Clethrionomys glareolus
}

\author{
K. M. Tähkä ${ }^{1}$, B. Fröysa ${ }^{2}$, S. Tähkä ${ }^{1}$ and O. Söder ${ }^{2}$ \\ ${ }^{1}$ Laboratory of Experimental Embryology, Department of Zoology, University of Helsinki, Finland; \\ and ${ }^{2}$ Pediatric Endocrinology Unit, Karolinska Hospital, Sweden
}

\begin{abstract}
Testicular interleukin-1-like factor (tIL-1) is a cytokine secreted presumably by Sertoli cells in several mammalian species. The function of this cytokine is unknown: tIL-1 may control meiosis, act as a mitogen for spermatogonia or have both of these functions. The present investigation was conducted to assess tIL-I activity and its hormonal control in a seasonally breeding photoperiodic mammal during testicular maturation and photoperiod-induced regression. Testicular maturation in long photoperiod ( $20 \mathrm{~h}$ light: $4 \mathrm{~h}$ dark) was accompanied by the appearance of tIL-1 activity at the age of 32-39 days which increased as full sexual maturity was reached. No significant tIL-1 activity was detected when pubertal development was inhibited or testicular regression induced by subjecting juvenile and adult bank voles to a short photoperiod ( $6 \mathrm{~h}$ light: $18 \mathrm{~h}$ dark) for 6 to 8 weeks. Administration of human chorionic gonadotrophin (hCG; $60 \mathrm{iu} \mathrm{kg}{ }^{-1}$ ) increased tIL-1 activity in sexually mature as well as regressed testes. In the photoregressed voles FSH $\left(1.2 \mathrm{U} \mathrm{kg}^{-1}\right)$ administration, which induced a three-fold increase in testicular weight and stimulated spermatogenesis, did not induce detectable concentrations of tIL-1. Administration of FSH followed by hCG increased tIL-I activity significantly in the atrophic testis, but this was probably due to hCG, since FSH treatment alone was without effect. In conclusion, in accordance with the proposed role of HIL-1 as a germ-cell mitogen and a meiosis-promoting factor, tIL-1 activity correlated positively with spermatogenic activity during testicular maturation and photoperiod-induced regression. IL-I production may depend on LH but not FSH. In bank voles and possibly other photosensitive seasonal breeders, photoperiod modulates the production of tIL-I indirectly through the neuroendocrine system.
\end{abstract}

\section{Introduction}

The mammalian testis produces numerous regulatory peptides that are involved in paracrine and autocrine modulation of gametogenesis and androgen synthesis (Parvinen et al., 1986; Tähkä, 1989; de Kretser, 1990; Tähkä, 1991). Currently, interest has focused on functional interactions between the immune system and gonadal cells (Söder et al., 1990). The testis has been known for some time to be an immunoprivileged site and since the efferent arm of the immune response appears to be operational in this organ it is assumed that there are paracrine mechanisms that inhibit antigen detection as well as the initiation of the immune response (Hedger et al., 1990; Pöllänen and Uksila, 1990). Immunoregulatory peptides may have other roles in the testis (Pöllänen et al., 1989; Bergh and Söder, 1990; Söder et al., 1991). It has been suggested that lymphocytes and germ cells have a common embryonal percursor (Friedman, 1987). In the testis, these factors could be used for other functional purposes, such as the paracrine modulation of spermatogenesis.

The human and rat testis produce a $17 \mathrm{kDa}$ cytokine (tIL-1) which is similar to the $\alpha$ isoform of macrophage-derived inter-

Received 13 April 1992 leukin I (Khan et al., 1987; Gustafsson et al,, 1988). tIL-1 is secreted bidirectionally, presumably by Sertoli cells, into the adluminal as well as the basal compartment and interstitial fluid. The production of tIL-1 is constitutive and appears to be under pituitary control (Maddocks et al., 1990; Söder et al., 1990). The functional role of tIL-1 remains obscure. However, some recent studies suggest that tIL-1 may act as a growth factor for germ cells and thus participate in the regulation of spermatogenesis (Pöllänen et al., 1989; Söder et al., 1991).

The reproductive response of bank voles (Clethrionomys glareolus) to photic stimuli is one of the most pronounced ever recorded for a mammalian species (Rowlands, 1936; Tähkä et al., 1983a). In bank voles, unlike golden hamsters, sexual maturation of juvenile weanling can be inhibited by light deprivation. Significant regressive changes in testicular histology, androgen synthesis and LH receptor content are encountered after only one week of short photoperiod treatment (Tähkä et al., 1983a, b; Tähkä and Rajaniemi, 1985). After 4-6 weeks of light deprivation, testicular weight is $3.3 \%$ of that of sexually mature individuals. The gonad is azoospermic, virtually devoid of meiotic stages and the Leydig cells are rudimentary and undifferentiated (Tähkä et al., 1983a; Tähkä, 
1988) and their capacity to produce androgens is defective (Tähkä et al., 1982, 1983a, b, 1991; Tähkä and Rajaniemi, 1985).

In the study reported here we attempted to clarify further the functional role of HIL- 1 in bank voles. Activity of tIL-1 was monitored with a sensitive murine thymocyte bioassay during normal sexual maturation and photoperiod-induced regression. The hormonal regulation of EIL-1 in the regressed and sexually active state was also investigated.

\section{Materials and Methods}

\section{Experimental procedures}

The sexual maturation of juvenile and adult voles (18-22 or 60-78 days old from our laboratory colony), born and reared in a long ( $20 \mathrm{~h}$ light: $4 \mathrm{~h}$ dark) photoperiod, was modulated by subjecting them for 14-17 and 42-56 days to a long ( $20 \mathrm{~h}$ light: $4 \mathrm{~h}$ dark) or short ( $6 \mathrm{~h}$ light:18 h dark) photoperiod. A control group of juveniles was killed at the age of 18-22 days.

The effect of administration of hCG (60 iu kg ${ }^{-1}$; daily s.c. injections for 5 days), FSH (1.2 $\mathrm{U} \mathrm{kg}^{-1}$, for 3 days) followed by hCG (60 iu kg ${ }^{-1}$, for 2 days) or FSH alone (1.2 $\mathrm{U} \mathrm{kg}^{-1}$, for five days) on testicular weight, histology and tIL-1 activity was studied in maximally photoregressed animals (weanlings exposed for 6-8 weeks to short photoperiod). The effects of hCG stimulation (60 iu $\mathrm{kg}^{-1}$ for 5 days) on sexually active adult voles (juveniles subjected for 6-8 weeks to long photoperiod) were also investigated. The animals were killed by cervical dislocation three days after the last injection. The left gonad was weighed, immersion fixed in Bouin's solution, processed for routine histology and stained with the haematoxylinperiodic acid-Schiff procedure. The right testis was stored in liquid nitrogen for HIL-I assay. Activity of tIL- 1 was monitored by a mouse thymocyte proliferation assay. Mice of the substrains $\mathrm{NMRI} / \mathrm{KI}$ and $\mathrm{NMRI} / \mathrm{H}$ acted as thymocyte donors and testicular extracts of Sprague-Dawley rats were used for checking the performance in the tIL- 1 assay.

\section{Chemicals and hormones}

Alpha-modified Eagle's Minimum Essential Medium ( $\alpha$-MEM) and fetal calf serum (FCS) were purchased from Flow Laboratories (Irvine, Ayrshire), phytohaemagglutinin-P from Difco (MI) and $\left[{ }^{3} \mathrm{H}\right]$ thymidine (TRA 120) from the Radiochemical Centre (Amersham). The gonadotrophic hormones hCG (CG 2, lot nr. 18F-0277) and porcine FSH (F 8001) were purchased from Sigma Chemical Co. (St Louis, MO).

\section{Extraction}

Testes were individually weighed and homogenized in saline $(1: 10, w: v)$ with a glass piston especially prepared to fit an Eppendorf tube. The homogenates were then centrifuged at $12000 \mathrm{~g}$ for $15 \mathrm{~min}$ at $4^{\circ} \mathrm{C}$ to remove non-dispersed material. The supernatants were individually collected and frozen at $-20^{\circ} \mathrm{C}$ until further processed. Protein concen- trations were measured according to the method of Bradford (1976).

\section{Interleukin 1 assay}

IL-1 activity was measured by a mouse thymocyte proliferation assay (Söder and Madsen, 1988), which is a modification of the method of Gery et al. (1972). Four- to eight-week-old mice of the NMRI substrain (here designated NMRI/KI), raised and kindly supplied by T. Midtvedt (Department of Microbiological Ecology, Karolinska Institute, Stockholm), served as thymocyte donors to the IL-1 bioassay. In contrast to the conventional NMRI mouse strain (here designated NMRI/H), the NMRI/KI substrain has been found to be highly responsive to IL-I. NMRI/KI mouse thymocytes at a concentration of $5 \times$ $10^{6}$ cells $\mathrm{ml}^{-1}$ were suspended in $100 \mu \mathrm{l}$ of $\alpha$-modified Eagle's Minimum Essential Medium ( $\alpha-\mathrm{MEM}$ ) containing 1\% FCS and $5 \mu \mathrm{g}$ phytohaemagglutinin-P ml $\mathrm{m}^{-1}$ and were incubated in flatbottomed 96-well plates (Lindbro; Flow Laboratories). Test material and standard and control material were added in a volume of $10 \mu \mathrm{l}$ to each well and the thymocytes were cultured for $46 \mathrm{~h}$, given a pulse of $\left[{ }^{3} \mathrm{H}\right]$ thymidine $(0.5 \mu \mathrm{Ci}$ per well $)$ and harvested at $48 \mathrm{~h}$.

Incorporated radioactivity was determined by liquid scintillation counting. The sensitivity of the assay is $1 \mathrm{pg} \mathrm{ml} \mathrm{m}^{-1}$ $\left(<60 \mathrm{f} \mathrm{mol} \mathrm{l}^{-1}\right.$ ) of recombinant IL-1 $\alpha$ and IL-1 $\beta$ (Granholm and Söder, 1991; O. Söder, unpublished). Under the above conditions the IL-1 bioassay does not crossreact with recombinant glycosylated human IL-6, recombinant human tumour necrosis factor, human and rat gamma-interferon, bovine and ovine inhibin or lipopolysaccharide from Escherichia coli (Granholm and Söder, 1991; Söder et al., 1990, 1991). In the initial experiments, individual testicular extracts from each group were pooled and the protein concentrations in all groups were adjusted to $5 \mathrm{mg}$ $\mathrm{ml}^{-1}$ by the addition of saline. The pools were assayed at six concentrations, each run in duplicate, to produce dose-response curves, starting with a protein concentration of $0.5 \mathrm{mg} \mathrm{ml}^{-1}$. From the results of the dose-response curves, a protein concentration of $0.25 \mathrm{mg} \mathrm{ml}^{-1}$ of testis extract was found appropriate for final analysis in the IL-1 bioassay. All testicular extracts were individually analysed in quadruplicate cultures at the above protein concentration and the mean c.p.m. values used for statistical analysis. The performance of the assay was judged by addition of a rat testicular extract known to contain high IL-1like activity (Khan et al., 1987).

The presence of possible crossreacting cytokines (IL-2, IL-4 and IL-7) in testicular extracts were excluded by using cultures of thymocytes from NMRI/H mice which are highly responsive to these interleukins but do not respond to IL-1.

\section{Statistical analysis}

The normality of the distribution and the homogeneity of variances were tested with the Kolmogorov-Smirnov test and Bartlett's test, respectively. Logarithmic transformation was used when necessary. One-way analysis of variance and Student's $t$ test were used for evaluating possible statistical differences between the experimental groups. When conditions for the 


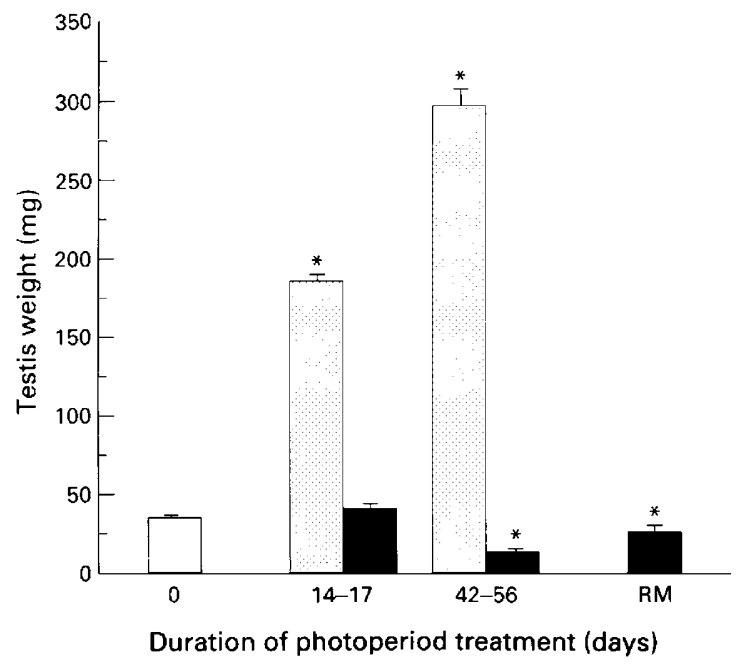

Fig. 1. Testicular weights of juvenile bank voles ( 0 days, $\square$ ) subjected for $14-17$ and $42-56$ days to a long ( $20 \mathrm{~h}$ light: $4 \mathrm{~h}$ dark, $\square$ ) or short ( $6 \mathrm{~h}$ light:18 h dark, $\mathbf{1}$ ) photoperiod. RM: adult, sexually mature voles rendered regressed by 42-56 days of short-photoperiod treatment. Values are means \pm SEM, $n=4-12$. *Significantly different from respective control, i.e. juvenile group $(P<0.05-<0.001)$.

use of parametric methods were not met Kruskal-Wallis and Mann-Whitney's $U$-test were applied.

\section{Results}

\section{Testicular weight and histology}

In accordance with our previous findings, photoperiod had a dramatic effect on the testicular maturation of bank voles. Longphotoperiod treatment permitted normal testicular maturation, whereas in the short photoperiod, it was arrested during the initial 2 weeks and subsequently regressive changes occurred (Fig. 1). Temporal changes in testicular histology during sexual maturation and photoperiod-induced regression were not investigated since this had been done previously by Tähkä $e t$ al. (1983a). hCG stimulation ( $60 \mathrm{iu} \mathrm{kg}^{-1}$ ) did not have a significant effect on the testicular weight of sexually active mature voles, whereas in the regressed voles, the hormonal treatments induced a two- to three-fold increase in testicular weight (Fig. 2). In the photoregressed voles, there were no prominent differences in testicular weight or histology between the different hormone-treated groups, except that Leydig cells were more differentiated in the voles treated with hCG. The hormone treatments stimulated spermatogenesis in the regressed testes. In general, spermatogenic activity was comparable to that encountered in juvenile animals, i.e. zygotene and pachytene spermatocytes were numerous and spermatids were occasionally present. Testes of control voles, receiving saline injections, were atrophic and virtually non-meiotic. With the exception of a few primary spermatocytes, the rudimentary seminiferous tubules were composed primarily of Sertoli cells and spermatogonia.

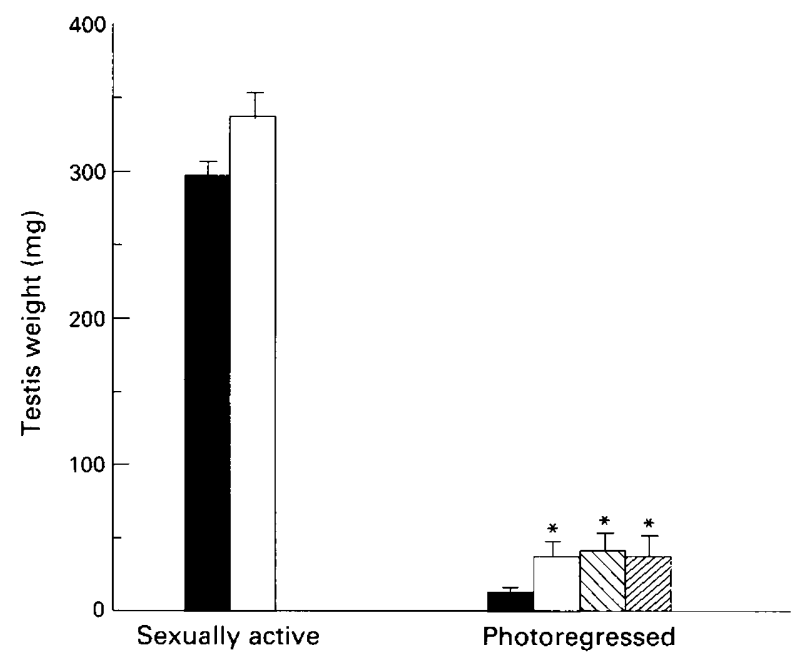

Fig. 2. Effect of different hormone treatments (daily s.c. injections for 5 consecutive days) on testicular weight of sexually active ( $20 \mathrm{~h}$ light: $4 \mathrm{~h}$ dark) and photoregressed ( $6 \mathrm{~h}$ light: $18 \mathrm{~h}$ dark) bank voles. ( $\square)$ Saline injections (control); ( $\square$ ) hCG (60 iu kg-1); (団) $1.2 \mathrm{U} \mathrm{FSH} \mathrm{kg}{ }^{-1}$ for 3 days followed by 60 iu hCG kg ${ }^{-1}$ for 2 days and (圈) FSH (1.2 $\mathrm{U} \mathrm{kg}^{-1}$ ) $n=5-11$. *Significantly different from respective control $(P<0.02-$ $<0.001)$

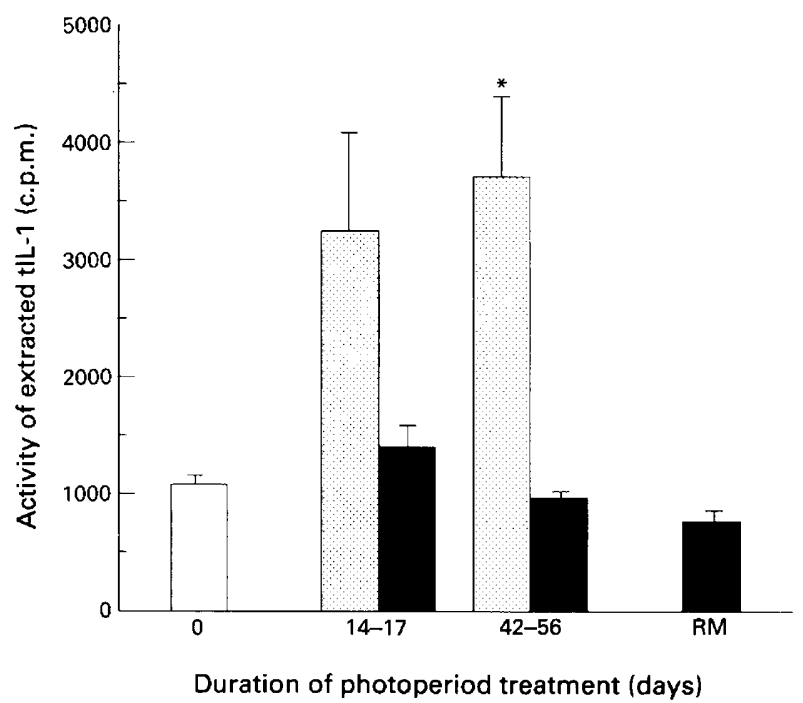

Fig. 3. Developmental and photoperiod-dependent regulation of testicular interleukin 1 (tIL-1) activity in bank voles. Values are means \pm SEM of 4-12 testes. ( $\square$ ) Juvenile voles killed immediately at the start of the experiment; $(\boldsymbol{D})$ voles treated with short photoperiod $(6 \mathrm{~h}$ light: $18 \mathrm{~h}$ dark) and ( $\square$ ) voles treated with long photoperiod ( $20 \mathrm{~h} \mathrm{light:4 \textrm {h }}$ dark). RM: adult, sexually mature voles rendered regressed by $42-56$ days of short-photoperiod treatment. "Significantly different from control, i.e. juvenile group $(P<0.01)$.

\section{Testicular interleukin 1 activity}

Testicular maturation in the stimulatory long photoperiod was accompanied by tIL-1-like activity at 32-39 days of age which increased as testicular maturation was completed at 60-78 days of age. In voles exposed to the short photoperiod, 


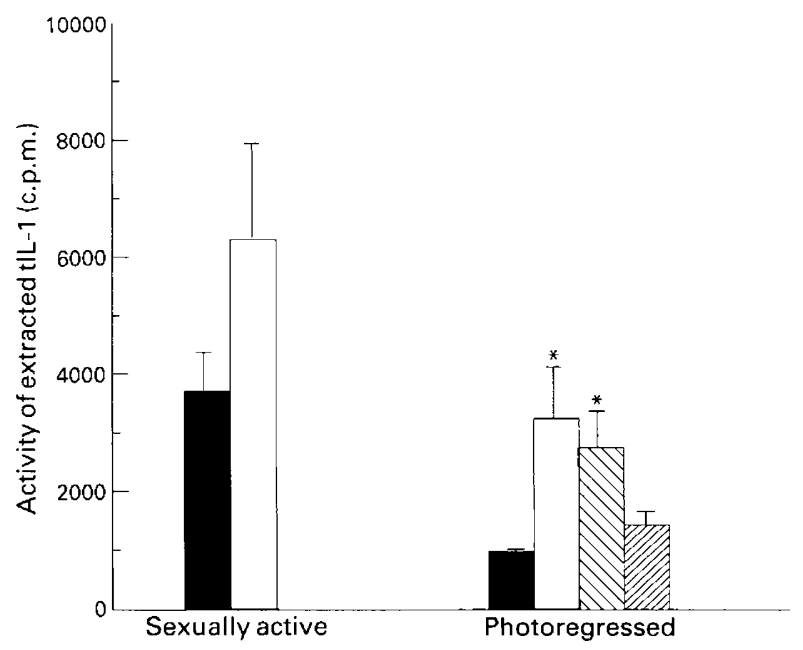

Fig. 4. Hormonal modulation of testicular interleukin I (tIL-1) activity in sexually active ( $20 \mathrm{~h}$ light: $4 \mathrm{~h}$ dark) and photoregressed $(6 \mathrm{~h}$ light: $18 \mathrm{~h}$ dark) testes of bank voles. ( $\square$ ) Saline injections (control); ( $\square$ ) hCG (60 iu kg ${ }^{-1}$ ); ( $\left(\right.$ ) $1.2 \mathrm{U} \mathrm{FSH} \mathrm{kg}{ }^{-1}$ for 3 days followed by $60 \mathrm{iu}$ hCG kg ${ }^{-1}$ for 2 days); (圈) FSH (1.2 $\mathrm{U} \mathrm{kg}^{-1}$ ); $n=5-11$; ${ }^{*}$ Significantly different from respective control $(P<0.001)$.

no fIL-activity was observed at any stage of testicular regression. HIL-I could also not be detected in the testes of voles that were permitted to reach full sexual maturity in the stimulatory photoperiod and then regressed by short photoperiod treatment (Fig. 3). Stimulation with hCG (60 iu $\mathrm{kg}^{-1}$ ) in vivo induced significant tIL-1 activity in the regressed, and increased the activity in the active testes. The combined treatment with FSH and hCG also induced significant activity in the regressed testes, but this was probably due to hCG, as stimulation with FSH alone was without effect (Fig. 4).

\section{Discussion}

The present study indicates that tIL-1 is present in the testes of bank voles. This is, to our knowledge, the first time that tIL- 1 activity has been monitored in a seasonally breeding mammal during pubertal development as well as photoperiod/ seasonally-induced regression. tIL- 1 activity has previously been detected in rat, human, mouse and rabbit but could not be found in shark, boar or ram testes (Söder et al., 1990). The functional significance of tIL- 1 is obscure. In extragonadal sites, IL- $\boldsymbol{I} \alpha$ is produced by activated macrophages, and is a mediator of inflammatory reactions, inducing leucocyte accumulation and participating in the immune response. However, IL- $1 \alpha$ and its testicular counterpart appear not to act as inflammatory mediators in the testis (Bergh and Söder, 1990). tIL-I may be involved in the modulation of testosterone synthesis. The effects of IL-1 $\alpha$ on testicular gonadotrophinsupported androgen production has been considered rather insignificant in comparison to IL-1 $\beta$ (Fauser et al., 1989; Calkins et al., 1990; Lin et al., 1991). However, there may be species specific differences in the ability of IL-I $\alpha$ to modulate testosterone production. Human recombinant IL- $1 \alpha$ has been found to be less potent than murine recombinant IL- $1 \alpha$
(Calkins et al., 1990). Moreover, human recombinant IL-1 $\alpha$ appears to act as a potent inhibitor of gonadotrophin-induced steroidogenesis in porcine but not in rat Leydig cells (Calkins et al., 1990; Maudit et al., 1992). tIL-1 may act as a growth factor for germ cells as intratesticular injections of human recombinant IL-1 $\alpha$ increase thymidine incorporation by intermediate and type B spermatogonia in hypophysectomized rats (Pöllänen et al., 1989). The production of tIL-I is stage specific in the seminiferous epithelium and correlates positively with DNA synthesis during the spermatogenic cycle. No significant IIL- 1 activity could be detected at substages VIlab and VIIcd in which DNA-synthesizing spermatogonia are sparse or lacking (Söder et al., 1991). IL-1 $\alpha$ also stimulates DNA synthesis in a stage-specific manner in seminiferous tubule segments in vitro (Parvinen et al., 1991). Furthermore, IL-1 is not only a mitogen for lymphocytes but also a known mitogen to diverse cell types such as glia cells, keratinocytes, chondrocytes as well as transformed cells (Giulian and Lachman, 1985; Ristow, 1987; Wakasugi et al., 1987; Söder and Madsen, 1988).

Our results on the ontogeny of tIL- 1 activity during normal sexual maturation and photoperiod-induced regression are in accordance with the proposed role of tIL-1 as a mitogen for germ cells. HIL-1 activity was first detected at puberty as spermatogenesis was activated and increased somewhat until full sexual maturity was reached, whereas it failed to appear when pubertal development and the initiation of spermatogenesis was arrested by light deprivation. HIL-1 activity also became undetectable in voles that had been sexually mature but then became sexually regressed through exposure to short photoperiod.

The dependence of tIL- 1 on the pituitary is evident from previous data since photoperiod-induced testicular regression is accompanied by a decrease in the secretion of pituitary gonadotrophins in the bank vole as well as in other seasonal breeders (Clarke 1981). Our results are in agreement with previous findings in rats. In this species, tIL- 1 activity is first encountered in early puberty and increases as testicular maturation proceeds (Syed et al., 1988). Hypophysectomy decreases IL-I receptors and IIL-I activity, whereas hCG administration induces increased activity (Söder et al., 1988; Pöllänen et al., 1990; Takao et al., 1990). The failure of testes from light-deprived voles to produce significant amounts of tIL- 1 is probably due to a pinealmediated decrease in pituitary gonadotrophin secretion (Farrar and Clarke, 1976; Versi et al., 1983). Experimentally induced germ cell damage (cryptorchidism, irradiation) has been found to induce a marked rise in tIL-1 activity (Khan et al., 1987; Syed et al., 1988). The fact that the regressed cryptorchid testes of bank voles did not contain tIL- $I$, is most probably due to insufficient hormonal support from the pituitary. In experimentally induced cryptorchidism, however, gonadotrophin secretion is intact and is, in fact, significantly increased.

Although it would appear that the constitutive production of tIL-1 by Sertoli cells depends on sufficient trophic support from the pituitary, the increase noted after administration of high doses of hCG may be at least partly due to the local production of some other effector(s), crossreacting in the thymocyte assay. hCG stimulation in adult rats increases, in addition to tIL-1 production, the secretion of a novel $38 \mathrm{kDa}$ cytokine (Söder et al., 1990). The cellular source of possible hCG-induced 
crossreacting agents is obscure. Infiltrating activated leucocytes could be one potential source. Macrophages may also be involved, since hCG treatment is known to increase their size as well as induce inflammation-like changes in the testis. A recent study (Bergh and Söder, 1990) suggests that stimulation with high doses of hCG may activate macrophages to secrete the leuko-attractant, IL-1 $\beta$. However, it would appear that resident testicular macrophages are deficient in their ability to secrete IL-1 when activated with Escherichia coli lipopolysaccharide (Guzzardi and Hedger, 1992). Leydig cells could alternatively be a source of hCG-induced IL-1-like activity. Wang et al. (1991) showed that IL-1 $\beta$ induces IL-I $\alpha$ mRNA in Leydig cells.

The study reported here provides evidence that supports the role of tIL-1-like factor as a germ cell mitogen. However, the species specificity of HIL-I, the bidirectional secretion of this cytokine and its high content in spermatozoa, as well as the diverse distribution of IL- $1 \alpha$ receptors in the testis and epididymis suggest multiple roles for this factor (for example, sperm maturation in the epididymis and control of testicular lipogenesis) (Syed et al., 1988; Grunfeld et al., 1990; Takao et al., 1990).

This study was supported by grants from the Swedish Medical Research Council, the King Gustav V Jubilee Foundation, Children's Cancer Foundation and the Finnish Society for Sciences and Letters.

\section{References}

Bergh A and Söder O (1990) Interleukin-1 $\beta$, but not interleukin- $1 \alpha$ induces acute inflammation-like change in the testicular microcirculation of adult rats Joumal of Reproductive Immunology 17 155-165

Bradford MM (1976) A rapid and sensitive method for the quantitation of microgram quantities of protein utilizing the principle of protein-dye binding Analytical Biochemistry 72 248-254

Calkins JH, Sigel MM and Lin T (1990) Differential effects of interleukin- $1 \alpha$ and interleukin-1 $\beta$ on Leydig cell function Biochemical and Biophysical Research Communications 167 548-553

Clarke JR (1981) Physiological problems of seasonal breeding in eutherian mammals. In Oxford Reviews of Reproductive Biology, pp 244-310 Ed. C Finn. Clarendon Press, Oxford

de Kretser DM (1990) Germ cell-Sertoli cell interactions Reproduction, Fertility and Development 2 219-223

Farrar GM and Clarke JR (1976) Effect of chemical symphathectomy and pinealectomy upon gonads of voles (Microtus agrestis) exposed to short photoperiod Neuroendocrinology 22 134-143

Fauser BC, Galway AB and Hsueh AJW (1989) Inhibitory actions of interleukin$1 \beta$ on steroidogenesis in primary cultures of neonatal rat testicular cells Acta Endocrinologica $120401-408$

Friedman NB (1987) The function of the primordial germ cells in extragonadal tissues International Joumal of Andrology 10 43-49

Gery I, Gershon RK and Waksman H (1972) Potentiation of the T-lymphocyte response to mitogens Journal of Experimental Medicine 136 128-142

Giulian D and Lachman LB (1985) Interleukin-I stimulation of astroglial proliferation after brain injury Science $\mathbf{2 2 8}$ 497-499

Granholm T and Söder $O$ (1991) Constitutive production of lymphocyte activating factors by normal tissues in the adult rat Joumal of Cellular Biochemistry 46 143-151

Grunfeld C, Soued Mr Adi S, Moser AH, Dinarello CA and Feingold KR (1990) Evidence for two classes of cytokines that stimulate hepatic lipogenesis: relationships among tumor necrosis factor, interleukin-1 and interferon-alpha Endocrinology 127 46-54

Gustafsson K, Söder O, Pöllänen P and Ritzén EM (1988) Isolation and partial characterization of an interleukin-1-like factor from rat testis interstitial fluid Journal of Reproductive Immunology 14 139-150

Guzzardi V and Hedger MP (1992) Comparison of bioactive interleukin-1 secretion and MHC II expression by testicular and peritoneal macrophages
Proceedings of the 7th Workshop on Molecular and Cellular Endocrinology of the testis, p 109. Ed. E. Nieschlag. Castle Elman, Germany

Hedger MP, Quin J-X, Robertson DM and de Kretser DM (1990) Intragonadal regulation of immune system functions Reproduction, Fertility and Development $2263-280$

Khan SA, Söder O, Syed V, Gustafsson K, Lindh M and Ritzén EM (1987) The rat testis produces large amounts of an interleukin-I-like factor International Journal of Andrology 10 495-503

Lin T, Wang D, Nagpal ML, Calkins JH, Chang W and Chi R (1991) Interleukin-1 inhibits cholesterol side-chain cleavage cytochrome P450 expression in primary cultures of Leydig cells Endocrinology 129 1305-1311

Maddocks S, Parvinen M, Söder O, Punnonen J and Pöllänen P (1990) Regulation of the testis Joumal of Reproductive Immunology 18 33-50

Mauduit C, Chauvin MA, Hartman DJ, Revol A, Morera AM and Benahmed M (1992) Interleukin-1 $\alpha$ as a potent inhibitor of gonadotropin action in porcine Leydig cells: sites of action Biology of Reproduction 46 1119-1126

Parvinen M, Vihko K and Toppari J (1986) Cell interactions during seminiferous epithelial cycle International Review of Cytology 104 115-147

Parvinen M, Söder O, Mali P, Fröysa B and Ritzén ME (1991) In vitro stimulation of stage-specific deoxyribonucleic acid synthesis in rat seminiferous tubule segments by interleukin-1a Endocrinology 129 1614-1620

Pöllänen P and Uksila J (1990) Activation of the immune system in the testis Joumal of Reproductive Immunology 18 77-87

Pöllänen P, Söder O and Parvinen M (1989) Interleukin- $1 \alpha$ stimulation of spermatogonial proliferation in vivo Reproduction, Fertility and Development $\mathbf{1}$ 85-87

Pöllänen P, von Euler M and Söder O (1990) Testicular immunoregulatory factors Joumal of Reproductive Immunology 18 51-76

Ristow H-J (1987) A major factor contributing to epidermal proliferation in inflammatory skin diseases appears to be interleukin- 1 or a related protein Proceedings of the National Academy of Sciences USA 84 1940-1944

Rowlands IW (1936) Reproduction in the bank vole (Evotomys glareolus, Schreber). I. Seasonal changes in the reproductive organs of the male Philo. sophical Transactions of the Royal Society Series B 226 99-120

Söder O and Madsen K (1988) Stimulation of chondrocyte DNA synthesis by interleukin-1 British Journal of Rheumatology 27 21-26

Söder O, Syed V, Pöllänen P, Gustafsson K, Granholm K, Khan, S, Arver S, Holst M, von Euler M. and Ritzén EM (1988) Testicular interleukin-1-like factor. In Molecular and Cellular Endocrinology of the Testis, Serono Symposia Vol, 50 pp 325-332 Eds B Cooke and R Sharpe. Raven Press, NY

Söder $\mathbf{O}$, Bergh A, Granholm T, Pöllänen $P$, von Euler $M$, Gustafsson $K$, Söderquist C, Lundström C, Arver S, Parvinen M. and Ritzén EM (1990) Interleukins in the testis. In Hormonal Communicating Events in the Testis, Serono Symposia Vol. 70 pp 105-113 Eds A Isidori, A Fabbri and M-L Dufau. Raven Press, NY

Söder O, Syed V, Callard GV, Toppari J, Pöllänen P, Parvinen M, Fröysa B and Ritzén EM (1991) Production and secretion of an interleukin-1-like factor is stage-dependent and correlates with spermatogonial DNA synthesis in rat seminiferous epithelium International Journal of Andrology 14 223-231

Syed V, Söder O, Arver S, Lindh M, Khan S and Ritzén M (1988) Ontogeny and cellular origin of an interleukin-1-like factor in the reproductive tract of the male rat International journal of Andrology 11 437-447

Tähkä KM (1988) Effect of differential photoperiod treatment on Leydig cell ultrastructure in the bank vole (Clethrionomys glareolus) General and Compara. tive Endocrinology $71318-330$

Tähkä KM (1989) Local control mechanisms in the testis International Joumal of Developmental Biology 33 141-148

Tähkä KM (1991) Cell to cell signaling and testicular function Advances in Comparative Endocrinology 1 I-31

Tähkä KM and Rajaniemi H (1985) Photoperiodic modulation of testicular LH receptors in the bank vole (Clethrionomys glareolus) Joumal of Reproduction and Fertility 75 513-519

Tähkä KM, Teräväinen T and Wallgren H (1982) Effect of photoperiod on testicular steroidogenesis of the bank vole (Clethrionomys glareolus, S). An in vitro study General and Comparative Endocrinology 47 377-384

Tähkä KM, Ruokonen A, Wallgren H and Teräväinen T (1983a) Temporal changes in testicular histology and steroidogenesis in juvenile bank voles (Clethrionomys glareolus, Schreber) exposed to different photoperiods Endocrinology 112 1420-1426

Tähkä KM, Teräväinen T and Wallgren H (1983b) Testicular steroid metabolism in juvenile bank voles (Clethrionomys glareolus) exposed to different photoperiods. An in vitro study General and Comparative Endocrinology 51 $394-400$ 
Tähkä KM, Tähkä S and Rajaniemi H (1991) Hormonal regulation of LH receptors in a seasonally breeding small mammal the bank vole (C. glareolus): Effects of photoperiod and sexual maturation Joumal of Reproduction and Fertility Abstract Series 8 Abstract $\mathbf{7 4}$

Takao T, Mitchell WM, Tracey DE and De Souza EB (1990) Identification of interleukin-1 receptors in the mouse testis Endocrinology 127 251-258

Wakasugi H, Rimsky L, Mahe Y, Kamel AM, Fradelizi D, Turz T and Bertogolio J (1987) Epstein-Barr virus-containing B-cell line produces an interleukin-1 that it uses as a growth factor Proceedings of the National Academy of Sciences USA 84 804-808

Wang D, Nagpal ML, Calkins JH, Chang W, Sigel MM and Lin T (1991) Interleukin- $1 \beta$ induces interleukin- $1 \alpha$ messenger ribonucleic acid expression in primary cultures of Leydig cells Endocrinology 129 2862-2866

Versi E, Chiappa SA, Fink G and Charlton HM (1983) Pineal influences hypothalamic Gn-RH content in the vole, Microtus agrestis Joumal of Reproduction and Fertility $67365-368$ 